\title{
Missionaries, Middle Age, and the Generative Life
}

\author{
David R. Dunaetz \\ Azusa Pacific University
}

\begin{abstract}
By the time career missionaries reach middle age, the risk of personal stagnation is high. Some missionaries, however, are very productive during this period of life. In Erickson's classic description of adult development, middle-aged adults who successfully navigate this period need to lead a generative life, learning how to positively influence future generations. This paper reviews recent literature on the predictors of generativity, including awareness of early blessings and calling, awareness of others' problems and pain, strong values and beliefs, pursuing goals to benefit others, and the presence of redemptive sequences in one's life narrative (the story that we tell ourselves and others which helps define our identity). Missionaries are encouraged to update their life narrative, going beyond the story of their conversion to Christianity, to include stories of how God has worked in their lives in recent years.
\end{abstract}

By the time missionaries reach middle age, quite a few things can be going wrong. Their kids may be struggling in the host culture. Their ministry might be advancing far more slowly than they ever thought possible. Because of limited opportunities for career advancement, they may be jealous or in competition with other missionaries. Their marriage may have become boring and their health may begin to decline. Their idealistic visions of their youth may have been replaced with the harsh realities of life. Advances in technology and changes in trends may leave them feeling hopelessly behind.

In such situations, the probability of ministry and personal stagnation is high. Some missionaries' life goals may be reduced to maintaining the status quo while retaining a bit of their dignity. However, other missionaries are extremely fruitful in middle age. Their focus is not on maintaining their own status or well-being, but on serving God and others in ways that will strongly impact future generations for good. In the 1950s, the psychologist Erik Erikson proposed that the most important struggle faced by middle aged adults is resisting the tendency toward stagnation and managing to live in a way that will positively influence future generations, a personal characteristic which he called generativity (Erikson \& Erikson, 1998). Although it's impossible to prove that this is the most important struggle that middle aged adults face, ample scientific evidence indicates that adults that are high in generativity, those who are very concerned about providing for the next generation, are happier, healthier, and more stable psychologically.

A recent study by researchers at Northwestern University (McAdams \& Guo, 2015) based on the life narratives of average North Americans has found several reliable predictors of generativity in the lives of middle aged adults. Generativity can be defined as "concern for and commitment to promoting the growth and well-being of future generations" (p. 475). It is measured by asking people how well they are described by statements like "I try to pass along knowledge I have gained through my experiences" and "I feel as though my contributions will exist after I die.” Clearly, for missionaries and all who care about fulfilling the Great Commission, generativity should be a high 
priority. Let's look at elements in a life narrative which are good indicators that a person will be highly generative (see the sidebar for more info about life narratives and how to shape them).

\section{Awareness of Early Blessings and Calling}

The first characteristic of middle aged adults who see themselves as generative is an early or longterm awareness of their strengths, gifts, or calling. People who are influencing future generations tend to

\section{Updating Your Life Narrative}

Most evangelical missionaries have developed a personal testimony describing their conversion or salvation story. However, many have not updated it to include the many changes that have occurred since their youth. If God has continued to work in our life, it would be good to make sure that stories of what he has done get incorporated into our life narrative, the story that we tell to ourselves (and occasionally to others) that describes and defines who we are. We typically use our life narrative to make sense out of new and difficult situations in which we find ourselves. So the more completely we can incorporate stories of God's grace and transforming power into our lives, the more likely we will be to integrate what we have seen him do in the past into what we are experiencing in the present.

McAdams \& Guo (2015) of Northwestern University found that middle aged adults who were the most generative (those who were the most concerned about and committed to promoting the well-being of younger generations) were those who "tend to understand their own lives as heroic tales of mission and transformation, wherein a gifted and morally steadfast protagonist journeys forth into a dangerous world, turning bad into good and giving back to society for early blessings received" (p. 476). Specifically, the narratives of generative middle agers included more stories of early advantages in life, sensitivity to others' needs, clear morals and values, multiple stories of bad situations being transformed into good, and goals for helping others than did the narratives of stagnating adults. Now these elements are exactly what characterize the lives of most missionaries. If we can successfully integrate them into the stories that we use to interpret the world as we move through middle age, we are more likely to avoid the stagnation, or even despair, that so often accompanies this period of life. describe themselves as having received special blessings or skills from birth or childhood. These blessings might include a stable family, an excellent upbringing, an outstanding education, or opportunities at an early age to learn things that most people do not. For Christians, these blessings might include putting one's faith in Christ at an early age which enabled him or her to avoid the sins which are so common in youth. Another possibility would be a radical conversion to Christ during the teenage years which enabled him or her to personally experience the transforming power of God. For missionaries, this awareness of early blessings encourages them to persevere in their current situation so that others can experience the same blessings.

In addition, people who describe themselves as having a special calling or having been especially equipped for certain tasks are more generative than people without this awareness. For missionaries, this might include their ordination, their commissioning, or any special calling they have received from the Lord. If we are certain (or at least reasonably certain) that God has called us to a task or ministry, this encourages us to stay focused on the task and measure our success by our faithfulness to this calling, even when there are few other signs of success. If a missionary is certain that he or she is called to serve the Lord through world evangelization, such a call will help him or her refocus when surrounded by unexpected difficulties such as failure, rejection, false accusations, abusive coworkers, family difficulties, or any other seemingly unsurmountable setbacks.

\section{Awareness of Others' Problems and Pain}

Another predictor of generativity in middle age that research (McAdams \& Guo, 2015) has found is a life narrative that emphasizes awareness and empathy for others' needs. These may be physical and related to poverty, such as insufficient food, water, shelter, or healthcare. Similarly, these needs may be psychological conditions, including depression, chronic anxiety, mental retardation, schizophrenia, and disorders relating to trauma, to name a few. This research also shows that middle aged adults who are living a fulfilling life that will benefit future generations may also be acutely aware of others' social needs, which, if unmet, may manifest themselves in crime, chemical dependency, domestic abuse, gambling, or other impulsive behaviors. As missionaries, we may especially be aware of others' spiritual needs, especially their need to be reconciled to God through Christ (2 Cor. 5:1820). 
Awareness of the needs of others enables us to focus our energy. If we are primarily concerned about our own needs, we are likely to have little time and energy left over for the needs of others. By focusing on the needs of others, even during difficult times we can make progress little by little, year after year. Seeing the needs of others met through our ministry provides a measure of how successful we are, encouraging us to continue, as well as providing a gauge by which we can fine tune exactly what we're doing to meet these needs. Yet even when we don't see success, we can continue to see the need which can motivate us to persist in ministry.

Historically, evangelical missionaries have primarily focused on responding to long-term spiritual needs, fulfilling the Great Commission through evangelism and church planting in order to make disciples of Jesus Christ. "What good is it if for someone to gain the whole world, yet forfeit their soul?" (Mark 8:36, NIV). However, Evangelical missionaries have also been involved in education, healthcare, famine relief, sustainable development, ministry to street children, refugee work, fighting human trafficking, and other ministries focusing on relief and development. By focusing on meeting these temporal needs, missionaries may be able to establish rapport which may open doors for the presentation of the gospel, especially if working among resistant peoples. On the other hand, a focus on temporal needs to the detriment of eternal needs may be costly in the long run.

\section{Strong Values and Beliefs}

A third characteristic found in middle aged people who are actively impacting younger generations is the possession of strong values and beliefs, whether they be religious, ethical, or political. For missionaries, these beliefs will especially be religious, and hopefully, ethical; missionaries' political beliefs are often muted in order to not distract from the message of the gospel or to reduce the risk of being expelled from their host country.

In Western cultures, it is currently not in style to have strong values or beliefs. The threat of receiving cutting, discouraging, and often anonymous criticism for believing anything that would limit unhindered pleasure seeking has become quite real in the age of social media. It is common to avoid any controversial subject in order to avoid offending someone and being labeled as intolerant or worse. Emotional reasoning has become the norm by which many people evaluate truth claims: "If I feel it is true, it must be true." Thus in order to avoid hurting the feelings of others and being exposed to their wrath, we are tempted to avoid expressing any controversial opinions, especially concerning sexuality or other ethically loaded topics. Nevertheless, middle aged adults who hold to their values and beliefs, and who act upon them, have a greater impact on the younger generations. They are more likely to avoid the stagnation which so often accompanies this period of life because they believe that these values can make a difference in the lives of others.

The values and beliefs that lead to generativity tend to be clear, consistent, and persistent. Values need to be clear in order to determine what our priorities are. What will determine how I use my time today? Missionaries are often surrounded by many people who have urgent needs, but are these the important needs that God has called us to meet? Are we listening to God's Spirit or are we succumbing to the tyranny of the urgent? It might feel good to spend a morning picking up a friends' brother from the airport or to help another missionary with a do-it-yourself project, but is this what God wants me to do? Is this what will have the greatest impact on future generations? By questioning our own behavior in light of our professed values, we will be able to better determine what our priorities should be.

Similarly, values and beliefs need to be consistent. Perhaps I value the idea of the young church I've helped to plant becoming independent of missionary help, but I also really like being appreciated by the young church and the comfort of the relationships I've formed. Such values can be in opposition to each other, distracting us from the task the Lord has given to us.

Values and beliefs need to be persistent.

Few major missionary goals are accomplished in just a few months or even in just a few years. We need to stay focused on long-term results, whether it's evangelism, planting churches, training leaders, or creating other organizations. If our priorities waver, if we follow after the whims of the moment or whatever ministry is stylish this year, our long-term results will be shallow or non-existent, having little impact on future generations.

In the field of social psychology, which studies the relationship between values and behaviors, the lack of consistency between values and behavior for most humans is a well-established fact. People say that they value something (helping orphans, defending human rights, evangelism, etc.), but there is little or nothing in their life that demonstrates these values. However, the one exception is when a person has intentions or plans to do something consistent with their values. If missionaries say they value evangelism (or some other ministry), but do not have plans to act upon this value, it is unlikely that the value will influence their 
behavior much. However, if they have the intention of specifically doing some sort of evangelism, if they make plans to evangelize, they will be much more likely to act upon their values.

\section{Redemptive Sequences}

The fourth element in one's life narrative that has been demonstrated to predict a generative life is the presence of redemptive sequences, stories of how one has gone through what seemed to be a negative situation but is now viewed as a positive situation because of the good that came from it. The first such experience that many Christians have is their conversion; in the midst of our sin and rebellion, God's grace enters our life and transforms us. Most of us have also continued to receive Christ's redemptive grace in new forms. Whether the bad situation is a result of our own sin, the sin of others, or apparently random, God continues to transform the bad into good. From a biblical perspective, this is one of the fundamental ways that God works in our lives. "Consider it pure joy, my brothers, whenever you face trials of many kinds, ..." (James 1:2ff). As missionaries, we encounter these negative situations regularly. If we can see how God transforms these situations into something good, and incorporate these stories into the way we regularly think about our life, our motivation will grow to help others so that they will have these same experiences when they face trials.

\section{Pursuing Goals to Benefit Others}

The final predictor of generativity in middle age is a life narrative that includes the pursuit of goals that benefit others, goals that benefit people outside of one's own family. McAdams and (2015) found this to be not just a predictor of generativity, but also of both creativity and psychological wellbeing. Middle aged missionaries who pursue goals that help others tend to be very concerned about these people, create new ways of achieving these goals, and avoid depression and anxiety because their focus is on others. Goals that are clear, consistent, and under the missionary's control are especially likely to have these positive effects.

The best way to see if a goal is clear is to ask if it is measurable: Can I tell when I have accomplished the goal and can move on to the next goal? For example, presenting the gospel to a person is a clearer goal than being a good witness to them. Starting a new church in a town with no evangelical witness is a clearer goal than evangelizing the town. Nevertheless, in missions there are so many uncertainties that often we do not know exactly how our ministries will pan out. We might plan one thing, but God has other plans. In spite of this uncertainty, we can try to be as clear as possible concerning our goals in order to better focus our efforts. However, this shouldn't hinder us from changing our goals if we have evidence that the Lord is leading us to do so. If our original plan is to start a church in Town A, but as the ministry progresses, we gather enough evidence to believe that God is leading us to start the church in Town B, we should change our goal from starting a church in Town A to starting a church in Town B.

To understand if our goals are consistent, we should ask if they work to contribute to a unified whole. Consistent goals contribute to an overarching higher goal. Meeting new people, inviting them over for tea, sharing the gospel with some of them, and starting a Bible study for those interested are all goals consistent with an overarching goal of starting a church.

Having goals that are under our control implies that their accomplishment depends primarily on our choice of behaviors. A goal of 10 baptisms per year is something that we as missionaries have little control of. Whether people decide to get baptized or not depends at least as much on them as it does on us. Such a goal also implies that God is working in other people's lives, something that we have little influence over. A better goal would be to preach a series of sermons on baptism or to offer a discipleship training program to each person who makes a profession of faith during the year. Such goals are within our control; we do not need to assume that God or the people whom we serve will act in certain ways.

\section{Conclusions and Applications}

Middle aged missionaries have likely gone through some very difficult situations. It is not rare to find that their youthful visions of changing the world have gradually morphed into a desire to maintain the status quo and eventually retire with dignity. However, some missionaries maintain a vision of the transforming power of Christ and actively invest themselves in serving future generations; rather than experiencing a life of stagnation, they experience generativity. The research we have examined indicates that people who have a life narrative emphasizing an awareness of one's calling, an awareness of others' suffering and needs, strong values and beliefs, and the pursuit of goals to benefit others are more likely to have a generative life than those who don't have these elements in their life narrative.

These life narrative elements fit perfectly in the Christian worldview, especially in the context of ministry and missions. Middle aged missionaries can reemphasize these elements as they evaluate their 
lives, updating their life narratives to fit their present context. Rather than allowing time and age to beat us down, we can refocus on what is important and use the remaining years of our ministry to serve future generations so that they might fully know Jesus Christ and live for his glory.

David R. Dunaetz, PhD, was a church planting missionary in France for 17 years. He is currently Assistant Professor of Leadership and Organizational Psychology at Azusa Pacific University and Adjunct Professor of French at Claremont Graduate University. He was motivated to write this article because of the suicide of one of his close friends.

\section{References}

Erikson, E. H., \& Erikson, J. M. (1998). The life cycle completed (Extended ed.). New York, NY: W. W. Norton \& Company.

McAdams, D. P., \& Guo, J. (2015). Narrating the generative life. Psychological Science, 26, 475-483. 